Supplement of Atmos. Chem. Phys. Discuss., 15, 33253-33282, 2015

http://www.atmos-chem-phys-discuss.net/15/33253/2015/

doi:10.5194/acpd-15-33253-2015-supplement

(C) Author(s) 2015. CC Attribution 3.0 License.

(c) (i)

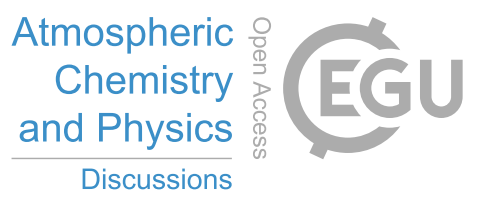

Supplement of

\title{
Time-resolved characterization of primary and secondary particle emis- sions of a modern gasoline passenger car
}

\section{P. Karjalainen et al.}

Correspondence to: T. Rönkkö (topi.ronkko@tut.fi)

The copyright of individual parts of the supplement might differ from the CC-BY 3.0 licence. 


\section{Supplement}

2 The emission factors $(\mathrm{mg} / \mathrm{km})$ obtained from the SP-AMS data are presented for different 3 parts of the test cycle in Figure S1 and Table S1.

4

(a)

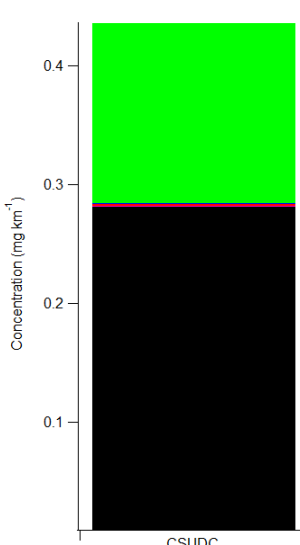

5

6

7 Figure S1. Emission factors ( $\mathrm{mg} / \mathrm{km}$ ) of primary (a) and secondary (b) particulate material for 8 different parts of the NEDC cycle.

9

10 Table S1. Emission factors for secondary components for different parts of the NEDC cycle.

\begin{tabular}{|l|l|l|l|l|l|l|}
\hline & ORG & $\mathrm{NO3}$ & $\mathrm{SO} 4$ & $\mathrm{NH} 4$ & $\mathrm{Chl}$ & $\mathrm{rBC}$ \\
\hline Part & $\mathrm{mg} / \mathrm{km}$ & $\mathrm{mg} / \mathrm{km}$ & $\mathrm{mg} / \mathrm{km}$ & $\mathrm{mg} / \mathrm{km}$ & $\mathrm{mg} / \mathrm{km}$ & $\mathrm{mg} / \mathrm{km}$ \\
\hline CSUDC & 9.38 & 0.139 & 0.0698 & 0.0253 & 0.000891 & 0.646 \\
\hline HUDC & 1.54 & 0.0127 & 0.0893 & 0.0154 & 0.000553 & 0.133 \\
\hline EUDC & 0.52 & 0.0417 & 0.0542 & 0.0187 & 0.000533 & 0.142 \\
\hline Total & 3.81 & 0.0645 & 0.0711 & 0.0198 & 0.000659 & 0.307 \\
\hline
\end{tabular}

11 (b)

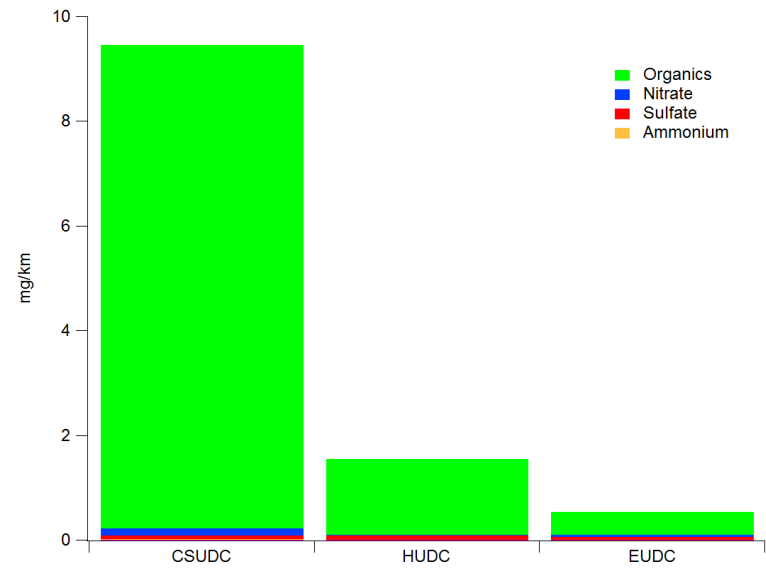

